\title{
Pendampingan dan Pengenalan Teknologi Berbasis Internet kepada Anak Berkebutuhan Khusus di SLB C Budi Daya, Jakarta Timur
}

\author{
Fitria Ayuningtyas $^{\mathrm{a}, 1, *}$, Vinta Sevilla ${ }^{\mathrm{b}, 2}$ \\ a,b Program Studi Ilmu Komunikasi, Fakultas Ilmu Sosial dan Ilmu Politik,Universitas Pembangunan Nasional Veteran \\ Jakarta, Jalan Raya Fatmawati No. 1, Pondok Labu, Jakarta Selatan \\ ${ }^{1}$ fitria.irwanto@upnvj.ac.id *; ${ }^{2}$ vintasevilla@upnvj.ac.id \\ * corresponding author
}

\section{ARTICLE INFO}

\section{Keywords}

Internet;

ICT;

$S L B$;

Children with Special Needs

\begin{abstract}
A normal child who is not lacking in anything physical or psychological is the dream of all parents. A hope regarding this matter is something that is natural for anyone. It's just that, in reality these hopes cannot be realized for some people. One of them is the presence of children with special needs in their lives. Even though every child has their own uniqueness and potential. One of the children with special needs is an autistic child. Autism is a very complex developmental disorder in a long life that includes disruption in aspects of social interaction, communication and behavior as well as emotional disturbances and sensory perceptions even in motoric aspects. Very severe disorders of some disorders experienced by children with autism that is a disorder in the ability to communicate. The ability to communicate nonverbally for children in general can be obtained naturally, without the need to be specifically and continuously taught for a long and long time. But the situation will be very different from autistic children. Autistic children need a design and learning strategy and approach to improve their nonverbal communication skills appropriately. Along with this, the development of Technology, Information and Communication (ICT) is inevitable. Most people think that the introduction and development of ICT knowledge is only for normal children. Through community service, the PKM team wants to share related developments in Technology, Information and Communication to children with special needs by using assistive devices and games specifically for children with special needs, especially children with autism. The implementation was carried out at SLB C Budi Daya, Cijantung, East Jakarta on 14 and 17 September 2018 ago.
\end{abstract}

\section{PENDAHULUAN}

\section{Latar Belakang}

Seorang anak normal yang tidak kurang suatu apapun baik fisik maupun psikologis merupakan idaman semua orangtua. Sebuah harapan terkait hal tersebut adalah sesuatu yang wajar bagi siapapun. Hanya saja, kenyataannya harapan tersebut tidak dapat terwujud bagi sebagian orang. Padahal setiap anak memiliki keunikan dan potensi masing-masing. Salah satu dari anak berkebutuhan khusus tersebut adalah anak autis. Autis merupakan gangguan perkembangan yang sangat kompleks dalam kehidupan yang panjang yang meliputi gangguan pada aspek interaksi sosial, komunikasi dan perilaku serta gangguan emosi dan persepsi sensori bahkan pada aspek motoriknya.

Gejala autis biasanya muncul pada anak-anak di kisaran usia 2-3 tahun. Di Indonesia sendiri, isu anak dengan gangguan autis ini muncul sekitar tahun 1990-an. Autis mulai dikenal secara luas di Indonesia pada tahun 2000-an. Data jumlah anak autispun hingga saat ini belum dapat diketahui secara pasti. Namun jumlah anak dengan gangguan tersebut menunjukkan peningkatan yang semakin signifikan dari hari ke hari.

Jika pada tahun 1990-an jumlah pasien yang di diagnosis sebagai anak dengan gangguan autis dalam setahun hanya sekitar 5 pasien baru, kini dalam sehari saja seorang psikiater di Jakarta 
dapat mendiagnosis 3 pasien baru. Dan hingga kini, penyebab pastinya kenapa anak dapat didiagonasis autis tersebut belum dapat ditemukan dengan pasti (Yuwono, 2012).

Sejarah munculnya terminologi autis pertama kali dicetuskan oleh Eugen Bleuler, seorang psikiatik Swiss pada tahun 1911. Dimana terminologinya tersebut digunakan pada penderita schizophrenia anak remaja. Kemudian pada tahun 1943, Dr. Leo Kanner dari John Hopkins University mendeskripsikan autis pada masa kanak-kanak awal, penemuan ini didasarkan pada hasil observasinya kepada 11 anak pada tahun 1938-1943 (Zimmerman, 2008).

Fakta mengenai autisme yaitu autisme terjadi pada 1 dari 68 anak, untuk saat ini tidak ada obat yang dapat diberikan untuk mengatasi gejala utama dari autisme tersebut dan setiap anak dengan gangguan autisme akan berbeda-beda, antara satu dengan yang lainnya.

Gangguan yang sangat berat dari beberapa gangguan yang dialami oleh anak autis yaitu gangguan dalam kemampuan berkomunikasinya. Kemampuan berkomunikasinya mengalami keterlambatan atau bahkan sama sekali tidak dapat berbicara, sehingga lebih banyak menggunakan bahasa nonverbal. Anak autis dapat di kelompokkan menjadi "mute" atau tidak dapat berbicara sama sekali dan dapat berbicara dengan cukup baik namun sering menggunakan bahasa echolalia yaitu menggunakan kata-kata yang diulang-ulang.

Kemampuan untuk berkomunikasi nonverbal bagi anak-anak umum dapat diperoleh secara alamiah, tanpa perlu diajarkan secara khusus dan terus menerus dalam waktu yang panjang dan lama. Namun situasi tersebut akan sangat berbeda dengan anak-anak autis. Anak autis membutuhkan suatu rancangan dan strategi serta pendekatan pembelajaran untuk meningkatkan kemampuan komunikasi nonverbal nya secara tepat.

Perkembangan Teknologi, Informasi dan Komunikasi (TIK) sangat dibutuhkan bagi semua orang. Sebagian besar orang berpikir bahwa pengenalan dan pengembangan pengetahuan TIK tersebut hanya dapat dilakukan pada anak-anak yang normal saja. Namun pendampingan untuk pengenalan tersebut juga penting diberikan kepada anak-anak berkebutuhan khusus terutama anak autis agar tidak adanya kesenjangan antara anak yang normal dan anak berkebutuhan khusus.

Berdasarkan hasil penelitian yang telah dilaksanakan oleh penulis sebelumnya beberapa waktu lalu, mengenai perlu adanya pendampingan, pengenalan dan pembelajaran kepada mahasiswa untuk penggunaan sumber informasi berbasis online/digital. Penulis menemukan temuan dalam penelitian tersebut bahwa pendampingan, pengenalan dan pembelajaran tidak hanya diperlukan bagi mahasiswa saja tetapi juga penting untuk siswa-siswa yang duduk di bangku sekolah.

Berdasarkan hasil penelitian tersebut, penulis melakukan observasi lanjutan untuk pelaksanaan PKM (Pengabdian kepada Masyarakat). Namun ada hal yang menarik menurut penulis setelah melakukan observasi lanjutan tersebut dimana terdapat suatu kekhasan dan keunikan ketika menempatkan pengenalan TIK kepada anak yang berkebutuhan khusus terutama anak autis. Sehingga penulis pun menyatakan bahwa anak berkebutuhan khusus juga perlu untuk dikenalkan dan diberikan pendampingan dalam menggunakan teknologi berbasis internet terutama anak autis.

Hal ini juga berkaitan dengan dukungan dalam bentuk komitmen konstitusional negara Indonesia bagi anak berkebutuhan khusus. Hal tersebut telah dijamin dalam perundang-undangan dan kelembagaan pemerintah Indonesia untuk meningkatkan perlindungan anak terutama anak berkebutuhan khusus tanpa adanya diskriminasi. Undang-undang Nomor 19 tahun 2011 mengenai Pengesahan Konvensi Mengenai Hak-Hak Penyandang Disabilitas dan diterbitkannya Peraturan Menteri Negara Pemberdayaan Perempuan dan Perlindungan Anak Nomor 10 Tahun 2011 mengenai Kebijakan Penanganan Anak Berkebutuhan Khusus. Kedua peraturan perundangan tersebut merupakan upaya pemerintah untuk memberikan perlindungan dan pelayanan yang layak untuk anak berkebutuhan khusus (Winarsih, 2013). Dalam rangka memberdayakan masa depan mereka terhadap pemenuhan hak asasi maka dirasa sangat perlu untuk menggaungkan hak asasi mereka dengan gigih.

\section{Permasalahan Mitra}

Berdasarkan hasil survei dan diskusi dengan Kepala SLB C Budi Daya, Jakarta Timur, maka dapat diidentifikasi beberapa permasalahan yang dihadapi oleh SLB C Budi Daya, Jakarta Timur adalah belum optimalnya pendampingan dan pengenalan teknologi berbasis internet kepada anak berkebutuhan khusus terutama anak-anak autis. 


\section{METODE PELAKSANAAN}

\section{Pendekatan Metode}

Kegiatan PKM yang dilakukan oleh tim pelaksana berdasarkan observasi awal sebelum terjun ke lapangan. Terdapat permasalahan mitra yang terjadi berkaitan dengan penggunaan teknologi oleh siswa berkebutuhan khusus, dalam hal ini yang dimaksud adalah siswa atau anak autis. Berdasarkan pemaparan sebelumnya bahwa anak autis tersebut butuh pengulangan dan membutuhkan pendampingan khusus untuk dapat memahami suatu objek. Adapun langkah atas permasalahan yang dialami oleh mitra dan untuk memberikan solusi, serta target dan luaran yang akan diperoleh dalam PKM ini, yaitu:

1. Permasalahan: Kurangnya pendampingan dan pengenalan teknologi berbasis internet kepada anak berkebutuhan khusus terutama anak autis.

2. Solusi dari permasalahan: Dibutuhkan dukungan/support yang nyata dan konsisten bagi anak berkebutuhan khusus terhadap pengenalan pada teknologi berbasis internet.

Sedangkan target luaran dari pengabdian kepada masyarakat ini adalah diadakannya pelatihan dan sharing mengenai pengenalan pada teknologi berbasis internet pada anak berkebutuhan khusus.

\section{METODE KEGIATAN}

Memiliki seorang anak di dalam keluarga merupakan sebuah rezeki dan kepercayaan yang diberikan oleh Yang Maha Kuasa kepada individu dan keluarga. Mendapatkan anak yang sehat jasmani dan rohani, dan tak kekurangan satupun menjadi harapan dari setiap orangtua dan para calon orangtua. Namun, terkadang ada berbagai faktor, akhirnya menghambat tumbuh kembang anak dan atau adanya gangguan pada perkembangan otak, akhirnya anak didiagnosis autis.

Sebagian orang berpikir ketika memiliki anak yang berkebutuhan khusus merupakan suatu masalah dikehidupannya, namun tidak sedikit pula yang berpikir dengan memiliki anak berkebutuhan khsus adalah sebuah amanah untuknya. Disini dapat dikatakan bahwa peran orangtua merupakan faktor utama untuk tumbuh kembang anak, dimana anak memberikan keterpercayaan yang penuh kepada orangtuanya. Tentu hal ini tidak hanya untuk anak yang normal saja, namun juga anak yang berkebutuhan khusus.

Menempuh pendidikan adalah keharusan untuk seorang anak. Rumah merupakan salah satu tempat atau pendidikan pertama yang didapat oleh mereka, kemudian sekolah. Sekolah adalah lembaga yang dirancang untuk pengajaran siswa/murid di bawah pengawasan guru. Sebagian besar negara memiliki sistem pendidikan formal, dimana segala sesuatunya sudah diatur oleh pemerintah dalam operasionalnya, kemudian orangtua menitipkan anaknya di sekolah-sekolah guna mengembangkan pengetahuan dan kreativitas anak.

Pendampingan yang dilakukan yaitu dengan usaha membantu agar anak-anak berkebutuhan khusus menemukan dan mampu mengembangkan kehidupan mereka yang lebih baik dan bermakna (Aziz \& Mangestuti, 2015). Dan dapat kita pahami bahwa keterbatasan bukanlah penghambat untuk mereka mengenal dan mempelajari dunia. Mereka dapat mengetahui dan mempelajari segala sesuatunya dengan beberapa proses dan tahapan pelatihan yang dilakukan secara bertahap, yang disebut sebagai pelatihan pengembangan hidup bermakna. Pelatihan untuk pengembangan hidup menjadi bermakna ini penulis merumpun beberapa tujuan, yaitu:

1. Membantu untuk setiap anak mampu mencapai tujuan hidup dengan adanya kegiatan dan melakukan hal yang berguna;

2. Membantu anak-anak agar dapat meraih kebermaknaan kehidupannya;

3. Membuat anak agar dapat meningkatkan kualitas hidupnya menjadi lebih baik;

4. Membantu dan menuntun individu agar dapat meningkatkan cara berpikirnya dan bertindak sekaligus berlaku positif; dan

5. Membantu anak agar mengembangkan potensi diri yang ia miliki.

Pendampingan yang dimaksud, yang dilakukan oleh penulis pada anak berkebutuhan khusus di SLB C Budi Daya, diharapkan siswa/i dapat:

1. Memahami peran mereka sebagai siswa yang memiliki potensi dan dapat memanfaatkan pembelajaran dari berbagai media, termasuk digital/ elektronik dan online. 
2. Lebih memahami dan memiliki rasa juang/berusaha dalam meningkatkan kemampuan berpikir dan bertindak positif dikehidupannya sehari-hari serta mandiri dalam melakukan segala sesuatu untuk dirinya.

3. Memahami dan memiliki tujuan dalam kehidupannya, serta mampu memanfaatkan TIK secara optimal.

Dalam mencapai tujuan, Bastaman (2004) menjelaskan tentang formula atau dapat disebut sebagai rumus pengembangan hidup bermakna dengan uraian, yaitu hidup bermakna diraih terlebih dahulu dikarenakan adanya niat dan tekad yang kuat untuk mengubahnya (niat), memiliki tujuan yang jelas (tujuan) dan usaha untuk mengaktualisasikan potensi diri yang dimiliki (potensi) serta memahami tentang asas kesuksesan (asas-asas kesuksesan), melaksanakan sesuatunya dengan penggunaan metode yang benar dan efektif (metode), dan adanya sarana (sarana). Selanjutnya, proses yang akan dilaksanakan ini akan lebih optimal jika didukung oleh lingkungan sosial (lingkungan) dan mendekat diri pada Yang Maha Kuasa yaitu dengan beribadah (ibadah). Dengan rumusan $\mathrm{HB}=(\mathrm{N}+\mathrm{T}) \mathrm{X}(\mathrm{P}+\mathrm{A}) \mathrm{X}(\mathrm{U}+\mathrm{M}+\mathrm{S}+\mathrm{L}) \mathrm{XL}$

1. $\quad \mathrm{N}$ (Niat). Niat yang dimaksudkan adalah segala sesuatu yang akan dimulai harus dimulai dengan niat yang baik. Niat merupakan motivasi yang ada didalam diri untuk maju dan menjadi lebih baik. Dalam hal ini adanya perubahan yang diinginkan oleh setiap individu dan berkeinginan untuk memiliki kehidupan yang bermakna. Adanya perasaan dan dorongan terhadap hidup bermakna atau dapat disebut juga the will to mean adalah motivasi atau dorongan yang diutamakan oleh manusia/ individu yang sifatnya instriksik atau dalam diri.

2. T (Tujuan). Ketika sudah adanya niat yang tertanam dari diri seseorang, maka ia akan memiliki tujuan dalam melakukan suatu tindakan, dimana adanya hal yang diharapkannya adalah suatu hal yang penting dan tentunya bermakna. Dalam pandangan psikologi, cita-cita merupakan sesuatu yang khas dan bersifat pribadi atau individu. Umumnya kebanyakan berorientasi dan condong pada kepentingan atas diri sendiri.

3. P (Potensi). Setiap manusia memiliki potensi dan keahliannya masing-masing. Potensi dan keahlian tersebut tidak lain dapat berupa fisik, mental, sosial dan juga spiritual. Banyak hal yang akhirnya potensi yang dimiliki tidak tersalurkan, atau mungkin tidak terlihat. Adanya potensi yang menjadi salah satu yang khas dimiliki oleh manusia adalah akal atau kecerdasan yang berhubungan dengan kognisi, dan kemampuan mengubah diri menjadi individu yang lebih baik.

4. A (asas-asas kesuksesan). Dalam maksud mengembangan hidup yang bermakna agar dapat berjalan dengan optimal, juga perlu diperhatikan dan dimengerti segala asas kesuksesan yang sebelumhya telah diuji. Pada pengembangan awal dapat dilakukan dengan pemurnian dan perbaikan terhadap karakter yang disertakan dengan etos kerja yang efektif.

5. U (Usaha). Segala pengharapan yang dicita-citakan akan terwujud ketika adanya usaha atau implementasi dari individu. usaha merupakan suatu upaya untuk mencapai keberhasilan. Disamping kerja keras (work hard), ada yang dinamakan sebagai kerja cerdas atau disebut dengan work smart dimana bekerja memanfaatkan sistem dan memanfaatkan SDA yang ada, metode dan juga sarana atau fasilitas yang tepat, dan kerjasama atau team work bersama orang lain. Dengan individu mampu mengerjakan seluruhnya maka dapat meningkatkan efisien dan efektifitas kerja.

6. M (Metode). Metode dalam sistem kerja adalah suatu hal yang harus dilakukan dengan tepat. Tidak adanya metode dan juga sistem yang tepat dan benar maka pekerjaan tentu akan tidak terarah, dan bisa saja akan sulit/terkendala untuk dicapai. Ketika bekerja dengan menggunakan metode yang tepat merupakan tanda bekerja yang cerdas. Pada kegiatan yang dilakukan dalam pendampingan hidup bermakna ini adalah dengan melaksanakan sesuatu dengan tepat dan berinovasi.

7. S (Sarana). Sama halnya dengan metode, ketika sarana digunakan dengan memanfaatkannya sebaik dan seefektif mungkin maka apa yang diharapkan akan dengan mudah dicapai. Alat atau sarana mencangkup sarana fisik dan mental, dimana sarana fisik diantaranya adalah tokoh teladan, masuk-masukan positif, buku-buku bermanfaat, kelompok yang positif, sedangkan sarana mental yaitu potensi diri, akal, iman, dan kemampuan mengubah nasib. 
8. L (Lingkungan). Lingkungan dan dukungan orang terdekat merupakan suatu hal yang paling berpengaruh besar untuk setiap individu. diistilahkan sebagai the significant other, contohnya yaitu keluarga dan juga sahabat (orang terdekat). Mengembangandan pengembangan diri, dan proses untuk hidup menjadi bermakna membutuhkan lingkungan yang seperti ini.

9. I (Ibadah). Pengembangan hidup bermakna yang terutama membutuhkan turut serta Yang Maha Kuasa, agar hidup akan lebih terarah dan mendapatkan kemudahan dari-Nya.

Adapun kegiatan yang telah kami lakukan pada tanggal 14 dan 17 September 2018 yang lalu di SLB C Budi Daya, Jakarta Timur adalah sebagai berikut :

1. Pemaparan Materi

Metode ini dipilih untuk menyampaikan konsep mengenai pendampingan dan pengenalan teknologi berbasis internet kepada anak berkebutuhan khusus. Adapun pemaparan materi yang telah dilakukan kami buat sesederhana dan semenarik mungkin agar dapat mudah dimengerti oleh anak-anak berkebutuhan khusus terutama anak autis.

2. Latihan/Praktik

Pemilihan metode ini bertujuan agar peserta secara langsung dapat berpartisipasi dalam kegiatan ini. Latihan yang kami lakukan mengumpulkan gambar-gambar sederhana terkait dengan internet dan bukan internet, sehingga peserta dapat berpartisipasi untuk membedakan mana gambar-gambar yang termasuk internet dan mana gambar-gambar yang tidak termasuk internet.

3. Evaluasi dan Tanya Jawab

Metode ini digunakan sebagai acuan untuk menilai seberapa besar kemampuan pemahaman peserta terkait konsep teknologi berbasis internet kepada anak berkebutuhan khusus terutama anak autis. Peserta yang dapat menjawab diberikan goodie bag menarik.

\section{Khalayak Sasaran}

Pelaksanaan pengabdian kepada masyarakat ini dilakukan di SLB C Budi Daya, Jakarta Timur. Adapun khalayak sasaran pada pengabdian kepada masyarakat ini yaitu anak-anak berkebutuhan khusus kelas VII, VIII, IX, X, XI dan XII khususnya anak autis.

Adapun sebelum melakukan pengabdian kepada masyarakat ini, tim melakukan permohonan izin kepada Kepala SLB C Budi Daya untuk melakukan pengabdian kepada masyarakat di sekolah tersebut, pencarian informasi terkait dengan karakteristik dari anak-anak berkebutuhan khusus yang ada di SLB C Budi Daya terutama anak autis, dikarenakan di SLB C Budi Daya ini kebanyakan siswanya adalah anak-anak autis. Hal tersebut dilakukan dikarenakan tim PKM ini belum pernah menghadapi anak-anak berkebutuhan khusus sebelumnya, survei tempat, perlengkapan dan peralatan di SLB C Budi Daya, mempersiapkan materi, goodie bag, dokumentasi dan plakat serta souvenir.

\section{HASIL DAN PEMBAHASAN}

\section{Hasil Pelaksanaan}

1. Persiapan Bahan dan Instrumentasi Pengabdian Kepada Masyarakat: Bahan dan Instrumentasi Pengabdian Kepada Masyarakat yang tim pelaksana gunakan adalah laptop, infocus, materi bahan PKM berbentuk PPT, spanduk, sertifikat bagi narasumber maupun mahasiswa pendukung dan penyerahan plakat kepada kepala sekolah serta dokumentasi dan pemberian goodie bag baik untuk siswanya maupun guru-gurunya. 


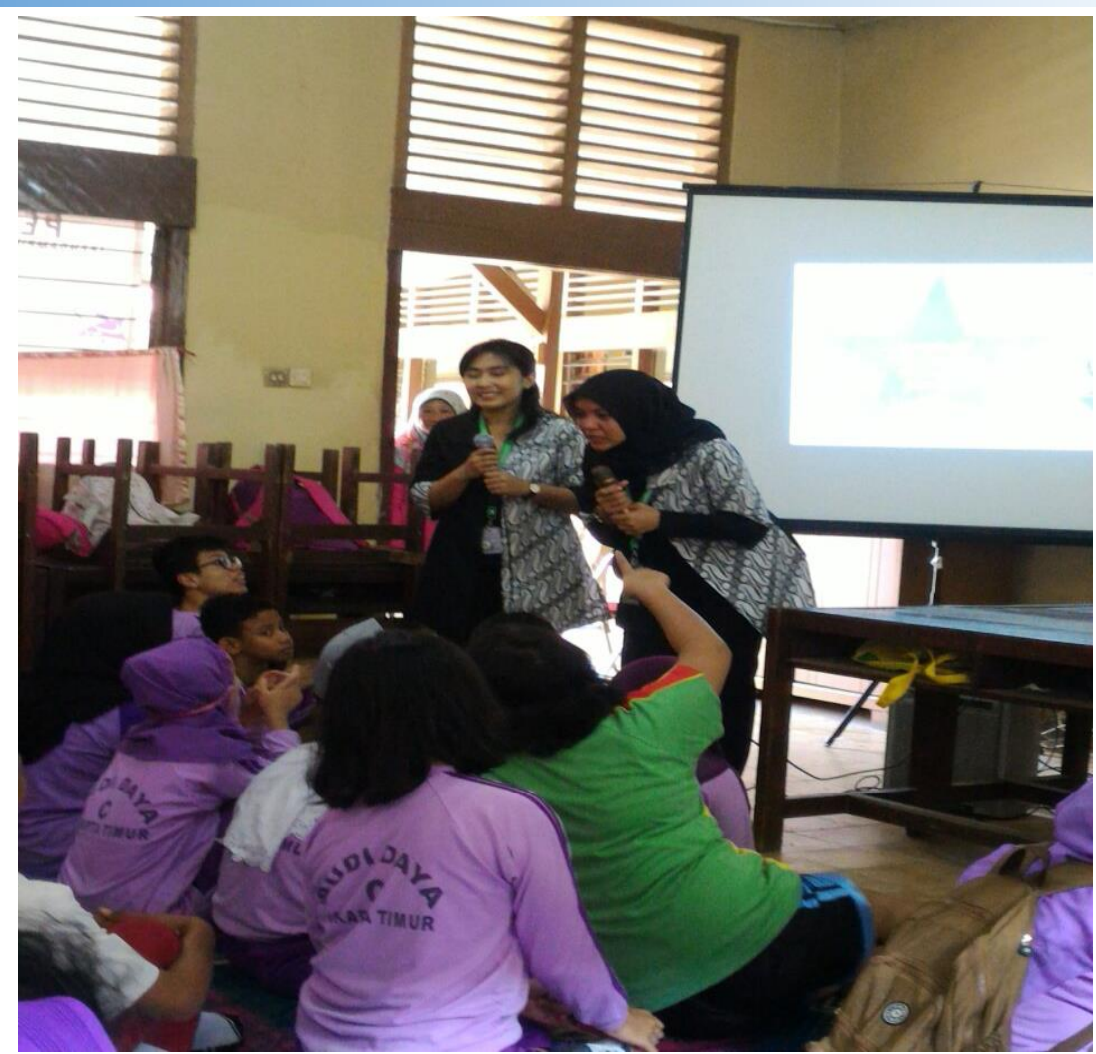

Gambar 1 Pemberian Materi Kepada Anak Berkebutuhan Khusus di SLB C Budi Daya

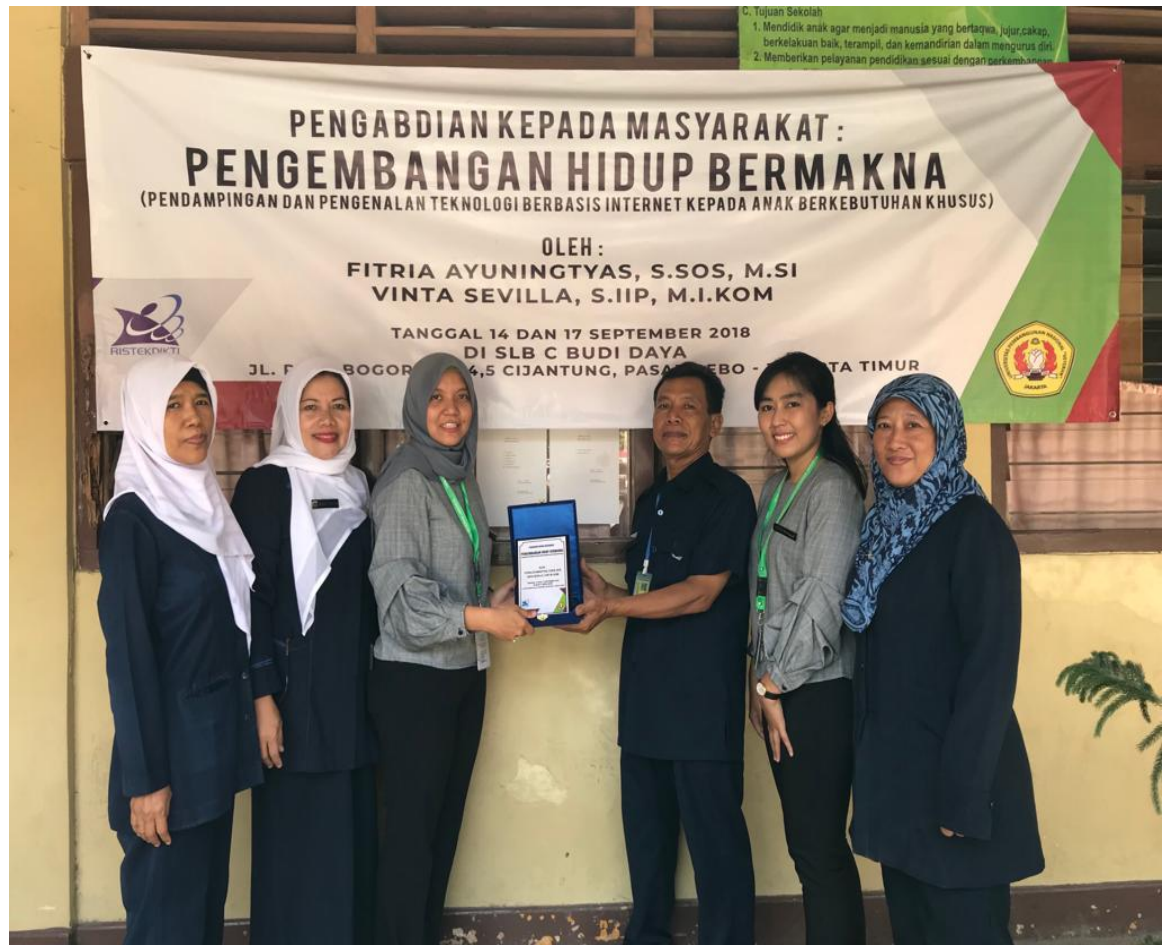

Gambar 2 Pemberian Plakat dan Souvenir kepada Kepala Sekolah di SLB C Budi Daya

2. Pelaksanaan Desain: Pelaksanaan PKM dilaksanakan dua tahap.

a. Tahap 1 dilaksanakan pada hari Jumat tanggal 14 September 2018, pada tahap ini narasumber yaitu Fitria Ayuningtyas, S.Sos, M.Si dan Vinta Sevilla, S.IIP, M.I.Kom memberikan pemaparan terkait dengan pendampingan dan pengenalan teknologi berbasis internet kepada anak berkebutuhan khusus kemudian diakhiri dengan tanya jawab dan juga pemberian games serta goodie bag. 


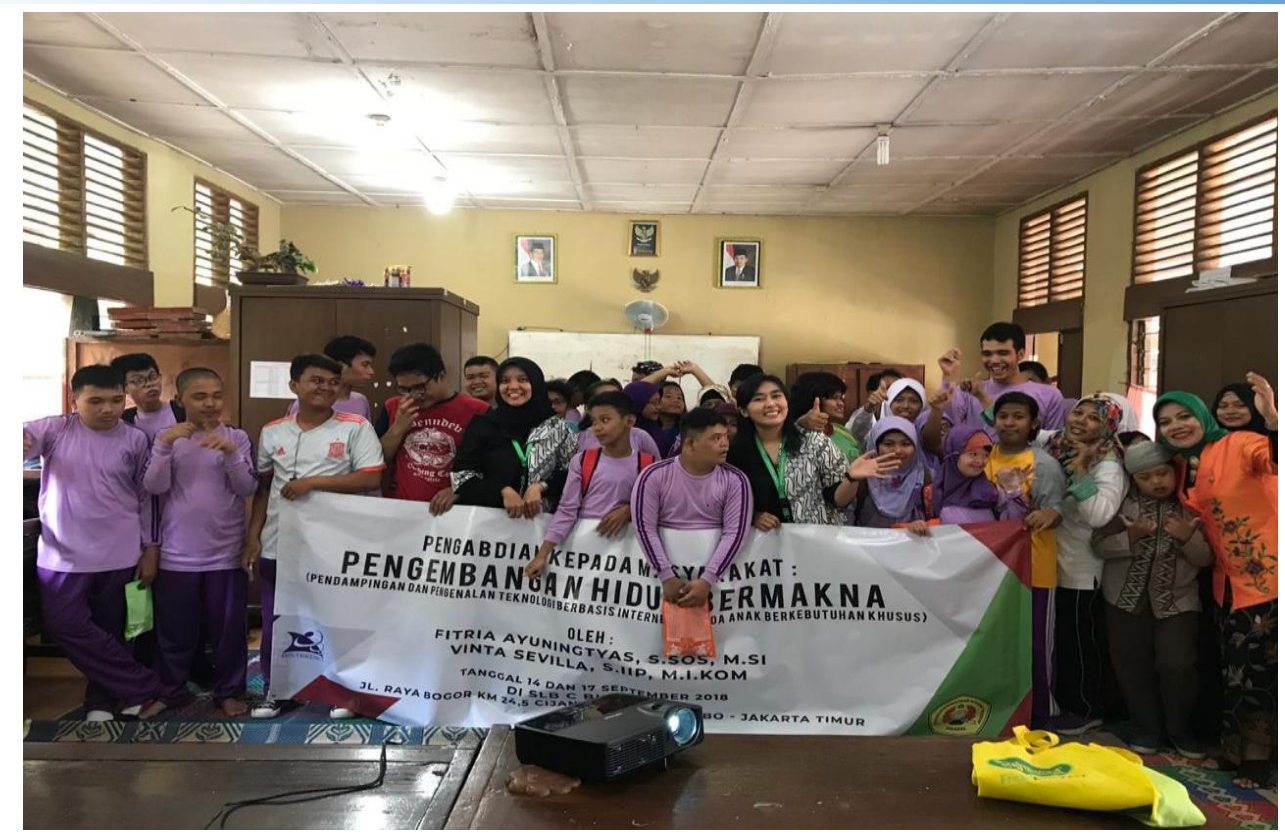

Gambar 3 Dokumentasi pengabdian kepada masyarakat tanggal 14 September 2018

b. Tahap 2 dilaksanakan pada hari Senin tanggal 17 September 2018, tim PKM melalukan tahap 2 dengan rentang waktu yang tidak jauh dari tahap I dikarenakan setelah berdiskusi dengan pihak SLB C Budi Daya, anak-anak berkebutuhan khusus terutama anak autis memiliki daya ingat yang tidak terlalu tajam sehingga jika rentang waktunya antara tahap I dan tahap II terlalu jauh khawatir mereka telah melupakan materi-materi yang telah dipaparkan sebelumnya di tahap I. Pada tahap ini narasumber yaitu Fitria Ayuningtyas, S.Sos, M.Si dan Vinta Sevilla, S.IIP, M.I.Kom memberikan pemaparan terkait dengan pengulangan materi mengenai pendampingan dan pengenalan teknologi berbasis internet kepada anak berkebutuhan khusus. Selain itu, materi yang disiapkan lainnya adalah berupa audio-visual dan video menarik yang ditampilkan untuk mereka kemudian diakhiri dengan tanya jawab dan juga pemberian games serta goodie bag.



Gambar 4 Dokumentasi pengabdian kepada masyarakat tanggal 17 September 2018

3. Tahapan Proses : Terselenggaranya pemaparan terkait dengan pendampingan dan pengenalan teknologi berbasis internet kepada anak berkebutuhan melalui berbagai proses yaitu:

a. Permohonan izin kepada Kepala SLB C Budi Daya untuk melakukan pengabdian kepada masyarakat di sekolah tersebut. 
b. Pencarian informasi terkait dengan karakteristik dari anak-anak berkebutuhan khusus yang ada di SLB C Budi Daya terutama anak autis. Hal tersebut dikarenakan tim PKM ini belum pernah menghadapi anak-anak berkebutuhan khusus sebelumnya khususnya anak autis.

c. Survei tempat, perlengkapan dan peralatan di SLB C Budi Daya.

d. Mempersiapkan materi, goodie bag, dokumentasi dan plakat serta souvenir.

\section{KESIMPULAN DAN SARAN}

\section{Kesimpulan}

1. Materi pelaksanaan Pengabdian kepada Masyarakat dirancang dan disesuaikan dengan kemampuan yang dimiliki oleh siswa/i SLB C Budi Daya. Materi tersebut terdiri dari gambargambar yang berhubungan dan yang tidak berhubungan dengan perangkat akses dan aplikasi yang terdapat di jaringan internet. Hal ini sekiranya mudah untuk ditangkap oleh anak-anak berkebutuhan khusus terutama anak-anak autis. Selain itu, materi yang disiapkan lainnya adalah berupa audio-visual dan video menarik yang ditampilkan untuk mereka.

2. Selama proses pelaksanaan kegiatan pengabdian kepada masyarakat, tanggapan serta respon siswa/i sangat beragam. Mengingat kemampuan, daya tangkap serta keterbatasan yang dimiliki oleh mereka pun berbeda. Secara keseluruhan dalam penyampaian materi, siswa/i SLB C Budi Daya senang dengan sesuatu yang mampu untuk menarik perhatiannya dan cara penyampaian materi yang atraktif.

3. Dilihat dari sisi keilmuan bidang TIK, kemampuan yang dimiliki oleh anak berkebutuhan khusus dalam penguasaan media, khsususnya siswa/i dalam tatanan sekolah sangat perlu untuk didampingi dan selalu ditinjau untuk penggunaannya. Pentingnya hal tersebut dikarenakan secara umum mereka mengetahui manfaat dari internet hanya sebatas hiburan dan alat komunikasi saja.

\section{Saran}

1. Pengenalan dan pendampingan secara berkesinambungan terhadap penggunaan dan pemanfaatan teknologi kepada anak berkebutuhan khusus sangat dibutuhkan. Hal ini dikarenakan hak belajar mereka yang pada prinsipnya sama dengan anak normal seusia mereka. Pengenalan dan pendampingan tersebut dapat berupa interaksi antara orang tua dan anak, guru dan anak dalam menggunakan komputer/laptop, handphone, tablet yang memiliki akses internet.

2. Setelah diberikan pengenalan, dan pendampingan kemudian anak berkebutuhan khusus hendaknya diberikan limit waktu dalam menggunakan gadget. Mengingat keadaan tersebut dapat memengaruhi dan merusak kesehatannya, dan tentu pula hal ini juga berlaku untuk semua orang.

\section{UCAPAN TERIMAKASIH}

Dalam pelaksanaan kegiatan pengabdian kepada masyarakat ini, tim pelaksana ingin mengucapkan terima kasih kepada beberapa pihak sebagai upaya apresiasi kami sehingga kegiatan ini dapat terlaksana dengan baik dan lancar. Apresiasi ini kami sampaikan kepada pihak-pihak antara lain:

1. Program Studi Ilmu Komunikasi, Fakultas Ilmu Sosial dan Ilmu Politik, Universitas Pembangunan Nasional Veteran Jakarta.

2. SLB C Budi Daya, Jakarta terutama kepada Kepala Sekolah beserta jajarannya dan juga semua guru-guru yang mendukung kegiatan ini.

\section{BIODATA PENULIS}

Fitria Ayuningtyas merupakan lulusan dari S1 Ilmu Administras Niaga, Institut STIAMI, Jakarta dan S2 Marketing Communication, The London School of Public Relations, Jakarta, salah satu dosen tetap dari Program Studi Ilmu Komunikasi, Fakultas Ilmu Sosial dan Ilmu Politik di Universitas Pembangunan Nasional Veteran Jakarta sekaligus Kandidat Doktor di Fakultas Ilmu 
Komunikasi, Universitas Padjadjaran, Bandung serta salah satu relawan di Rumah Autis cabang Depok sebagai pengajar.

Vinta Sevilla lulusan dari S1 dan S2 dari Fakultas Ilmu Komunikasi, Universitas Padjadjaran, Bandung merupakan salah satu dosen tetap dari Program Studi Ilmu Komunikasi, Fakultas Ilmu Sosial dan Ilmu Politik di Universitas Pembangunan Nasional Veteran Jakarta sekaligus menjabat sebagai Ka. UPT Perpustakaan Universitas Pembangunan Nasional Veteran Jakarta.

\section{DAFTAR PUSTAKA}

Aziz, R., \& Mangestuti, R. (2015). Pengembangan Hidup Bermakna. Malang. Retrieved from http://repository.uin-malang.ac.id/439

Bastaman, H. (2004). Logoterapi:Psikologi untuk Menemukan Makna Hidup dan Meraih Hidup Bermakna. Jakarta: PT Raja Grafindo Persada.

Winarsih, S. (2013). Panduan Penanganan Anak Berkebutuhan Khusus bagi Pendamping. Jakarta: Kementerian Pemberdayaan Perempuan dan Perlindungan Anak.

Yuwono, J. (2012). Memahami Anak Autis: Kajian Teoritis dan Empirik. Bandung: Alfabeta.

Zimmerman, A. (2008). Autism: Current Theories and Evidence. USA: Springer. 